\title{
A KÜLÖNLEGES MENTÉSI FELSZERELÉSEK BIZTONSÁGOS HASZNÁLATÁNAK ELEMZÉSE STATISZTIKAI MÓDSZEREKKEL, II. RÉSZ
}

\section{STATISTICAL METHODS FOR ANALYSIS OF SAFE USE OF SPECIAL RESCUE EQUIPMENT, PART II.}

\author{
JACKOVICS Péter \\ (ORCID: 0000-0002-1809-029X) \\ peter.jackovics@katved.gov.hu;
}

\begin{abstract}
Absztrakt
A katasztrófák és a balesetek fokozódó extrémitása miatt a mentési müveletek egyre összetettebbé váltak, ez pedig mind elméleti és mind gyakorlati szempontból jobban felkészült mentési szakszemélyzetet kíván meg. Komoly problémát jelent, hogy a különleges mentéseknél alkalmazott eszközök használatának módszerei sok esetben csupán „szájhagyomány” alapján terjednek, miközben a gyártók által a kifejlesztett eszközpark viszont dinamikusan fejlödik.

A közlemény célja, hogy egy erre a célra tervezett direkt választási módszerrel végzett kutatás eredményeinek faktoranalízissel történő feldolgozása egyfelöl megválaszolja azt a kérdést, hogy a felhasználók hogyan ítélik meg három kiválasztott konkrét kötéltechnikai eszköz biztonságos használhatóságát, másrészt pedig erre támaszkodva biztonságnövelő javaslatokat fogalmazzon meg ezen eszközök használatával kapcsolatban.

A cikk második részében Q-módszertannal vizsgálom a biztonságos eszközhasználatot, amelybe bedolgoztam a korábban kapott statisztikai eredményeket, gyártói értékeléseket.
\end{abstract}

Kulcsszavak: Kötéltechnika, Mentési felszerelés, Faktoranalízis, Biztonság, Qmódszertan

\begin{abstract}
Due to ever increasing extremities of disasters and accidents, rescue operations have become more and more complicated, requiring both theoretically and practically better qualified rescue personnel. It is a serious problem that methods of using special rescue equipment, rely in many cases only on oralbased communication, while the offer of new equipment's developed by manufacturers is growing dynamically.

The purpose of the article, based on forced distribution processing of the results of case study to prepare with Factor Analysis, is to answer the question how the users evaluate the usage safety of three selected rope technological devices. An additional purpose was, based on these results, to make suggestions on improving usage safety concerning these devices.

In this second part of my article, I analyze the results with Q-methodology for the safe use of equipment, in which I have used the previously given statistical results from study of Part I. and lesson learned.
\end{abstract}

Keywords: Rope technique, Rescue equipment, Factor Analysis, Safety, Qmethodology 


\section{BEVEZETÉS}

Biztonságtudományi doktori iskolai kutatás keretében vizsgáltam három kiválasztott konkrét kötéltechnikai eszköz felhasználóinak a véleményét ezen eszközök biztonságos használhatóságáról, valamint alkalmazási és döntési szokásait a felszerelések kiválasztása és használata oldaláról. Az eredményről két részletben számolok be.

A tanulmány első részében bemutattam egy 52 kérdéses kérdőív eredményét, amelyet a kötéltechnikai mentéssel, hegymászással, ipari alpintechnikával, barlangi mentéssel és barlangászással foglalkozó szakembereknek, sportolóknak, hivatásos tüzoltóknak és kedvtelési céllal kötéltechnikai eszközöket használó civileknek szántam. Három konkrét kötéltechnikai eszköz vizsgálatát céloztam meg. Kettő eszköz speciális, de a különböző gyártók által kifejlesztett, összetett mechanikai müködésü, modern, magasabb árfekvésü eszköz a mászógép és az ereszkedőgép. A harmadik egy hagyományos, más eszközzel legtöbbször együtt használatos felszerelés, a karabiner, amelyet a gyártók a zárszerkezet és anyagösszetétel tekintetében fejlesztettek tovább. Mindhárom eszköz ma már nagyon népszerü és közkedvelt a felhasználók körében. A kérdőív elsősorban a három felszerelés biztonságos használhatóságáról, illetve a kiválasztás szempontjairól kérdezte a válaszadót.

A kötéltechnikai eszközök használatára vonatkozó felmérés eredményeinek ismeretében - a tanulmány első részében - több statisztikai módszerrel (Mann-Whitney próba; Spearman-féle rangkorreláció) megvizsgáltam a kérdöívre adott válaszok hátterét. Az eredmények értékelését követően szakmai döntés után 4 szempont alapján dolgoztam fel az 52 kérdéses kérdöív válaszait:

1. Felszerelés biztonságos használata;

2. Felszerelés kezelhetősége;

3. Gyártói előírás, felhasználói utasítás;

4. Design (kialakítás), termék beszerzési ára.

A válaszadók összegzett értékítélete alapján azonban megállapítható volt, hogy, a biztonság, a kezelhetőség és a gyártói utasítás hármasa mentén választanak kötéltechnikai felszerelést. A statisztikai módszerekkel végzett első körös elemzés alapján láthatóvá vált, hogy a kötéltechnikai felszerelések felhasználói esetében erősíteni kell a biztonságos eszközhasználat szempontjait, a más eszközzel történő együtthasználat kötelmeit, összetettebb eszközhasználat esetén pedig a felszerelések alkalmazásba helyezésének alapvető szabályait.

A mentőszervezeteknek és a gyártóknak törekedni kell olyan szervezeti intézkedések meghozatalára, ahol senior szakértő vezetésével vagy oktatóval az elmélet-igényes gyakorlás útján a felhasználók elsajátítják a kötéltechnikai alapfelszerelések együtthasználatát. A tanulmány első részében, a leíró statisztikákra támaszkodva olyan szakmai javaslatokat sikerült megfogalmazni, amely a kötéltechnikai sport célú és kötéltechnikai-mentési tevékenység baleseti kockázatát csökkenthetjük. Felkészültek akkor lehetünk, ha a kötéltechnikai eszközök használatát rendszeresen gyakorolják a felhasználók, figyelembe veszik a gyártói, szervezeti utasításokat, nemzeti szabályozókat. Balesetek bekövetkezési esélyét pedig csökkenthetjük, ha a felszereléseink jól karbantartottak, illetve más felszereléssel történő együtthasználatuk során a kompatibilitást megfelelöen figyelembe vesszük.

A kötéltechnikai eszközök balesetmentes használatában a felkészült felhasználó (egyén), a szigorú gyártói elöírások, karbantartott felszerelés, eljárásrendek együttesen rendelkezésre állása szükséges. Fontos, hogy a résztvevők betartsák a munka- és balesetvédelmi, valamint a belső szervezeti elöírásokat.

A tanulmány második részében célom, az hogy az első részben bemutatott reprezentatív csoporton végzett kutatási eredményeket megerősítsem egy kis létszámmal végezhető módszerrel. A Q-módszertan bevonásával a kötéltechnikai mentési felszerelések biztonságos 
használatára megfogalmazott állítások már a biztonság, a kezelhetőség és a gyártói utasítás hármasa mentén lettek megfogalmazva. Az így összeállított állítások kiválasztását - a mászógép, az ereszkedőgép és a karabiner tekintetében - a HUNOR Mentőszervezet kötéltechnikai elegységével végeztem el.

\section{A Q-MÓDSZERTAN ALAPELVE}

A Q-módszertan egy olyan gyakorlati szempontból jól átgondolt és matematikailag is megalapozott módszertan és szemlélet, amelyet az emberi szubjektív véleményeknek az elemzésére és megjelenítésére fejlesztett ki William Stephenson (1953), amerikai fizikus és pszichológus. Újszerüsége abban rejlik, hogy számszerüsítve képes megjeleníteni egy adott személyen belüli vagy egy csoportban megjelenő vélemény-mintázatokat. A Q-módszertan matematikai hátterét egy speciális korrelációszámítás és egy módosított szemléletü faktoranalízis adja, amelyek segítségével a hasonló véleményekböl közös csoportokat, faktorokat hozhatunk létre [1].

A módszertan nem követeli meg a kvantitatív elemzések megbízhatóságához szükséges mintanagyságot, ezzel egyidejüleg nem alkalmas reprezentatív típusképzésre, csak tipikus véleményformák előállításával segíti felmérést végzőt a mintázatok felismerésében [2]. A vizsgálatba viszonylag kevés, általában csupán néhány (tipikusan 4-20) jól kiválasztott - de több instrukció szerinti rendezés esetén akár egyetlen - személyt vonnak be, akiket meghatározott kritériumok alapján választanak ki. Jellegzetességei miatt a Q-módszertan összekapcsolja a kvalitatív es a kvantitatív kutatási eljárásokat, kombinálva mindkét kutatási módszer előnyeit [2]

A Q-módszertan egzakt, tudományosan jól megalapozott tudományfilozófiai és statisztikai módszertani keret és szemléletmód, amelynek segítségével a különböző egyéni módokon megélt pszichológiai helyzetekhez kapcsolódó szubjektivitás objektív tudományos eszközökkel mennyiségileg megragadható [4]. Ez a megközelítés egyesíti a kvalitatív és a kvantitatív kutatási tradíciók erejét. A hagyományos korrelációs pszichológiai adatelemző eljárások során általában teszteket vagy más mérőeszközöket alkalmaznak személyek egy mintájára és a korrelációs együtthatókat a tesztek, mint változók között számítják ki [5][6]. A Q-módszertan ezzel szemben alapvetően személyeket (illetve instrukciókat) alkalmaz állítások vagy más hasonló megítélhető ingerek egy mintájára és a korrelációs együtthatókat a személyek (illetve instrukciók), mint változók között számítja ki. A Q-módszertan alkalmazásának második lépésében, legtöbbször ezen korrelációs együtthatók alapján, egy faktoranalízis elvégzésére kerül sor [7][8].

A Q-módszertanban a normalitás az ún. „kényszer-választás” technikával már eleve biztosított, az eredmények értelmezhetősége ezért teljes értékü. A „kényszer-választás” abban áll, hogy a válaszadóknak az állításokat egy normális eloszlást közelítő „keretbe” kell rendezniük. A kényszerválasztáshoz alkalmazott értékrács kialakítását a 1. ábra szemlélteti. A két szélső véleményhez kerül a legkevesebb állítás, majd a skála közepe felé haladva egyre több állítás kerül az egyes kategóriákba, míg végül a középső kategóriába fog a legtöbb állítás kerülni. Az ezzel az osztályozással kapott új skála mindenképpen páratlan fokszámú és a skála eloszlása jól közelíti a normális eloszlást [9][10]. 


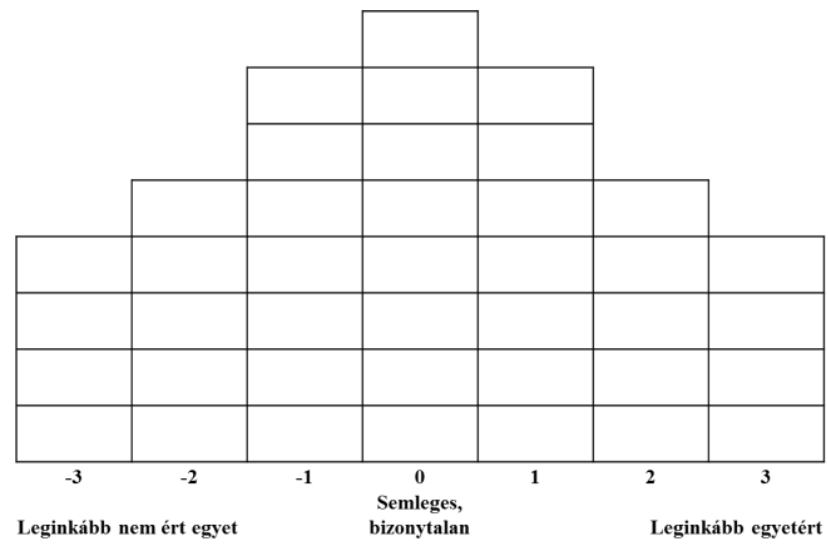

1. ábra A Q-módszertan „kényszer-választás” technikája: 40 állítás rendezése, 7 fokozatú skálán (saját szerkesztés)

A faktoranalízis alkalmazása akkor célszerü, ha exploratív elemzést kell végezni. Az elemzés lépései ilyenkor [11]:

1. Állítások megfogalmazása.

2. Adatgyüjtés ,kényszer-választás” technikájával.

3. A faktoranalízis elvégzése a faktorpontok elemzésével.

4. A legerősebb faktorpontok értelmezése a faktorpontok, illetve az azokhoz tartozó szélsőséges kategóriákba tartozások alapján.

\section{A Q-MÓDSZERTAN ALKALMAZÁSA}

A tanulmány első részében bemutatott statisztikai módszerek eredménye alapján kidolgoztam 40-40 állítást, amelyek segítségével a biztonságos használatra kapott eredmények mélyebb magyarázatát vártam a kiválasztott szakértőktől. Amint már jeleztük, a Q-módszertannal elegendő lehet kis létszámú - de egyébként jól kiválasztott - vizsgálati minta bevonása.

Az alkalmazott 40 állításról hétfokozatú $(-3,3)$ válaszrács segítségével kértem válaszokat a vizsgálatba bevont 7 személytől, akik a HUNOR Mentőszervezet kötéltechnikai egység tagjai, az állításokat és a kiadott feladatot az 1. függelék tartalmazza. A -3 érték felel meg annak, hogy az adott állítással a válaszadó szakértő egyáltalán nem ért egyet, míg a 3 érték annak, hogy az adott állítással teljes mértékben egyetért. A gyakoriságok összege 40. Valamennyi résztvevőnek az állításokat kártyákra nyomtatva készítettem elő, valamint eszközcsoportonként egy-egy válaszrácsot biztosítottam. Az adatok elemzését, az értékek kiszámítását ebben az esetben is az IBM SPSS Statistics 23 szoftvercsomag segítségével végeztem el.

A kiválasztott szakértők 25-45 év közötti férfiak, akik 5-25 év közötti gyakorlati idővel rendelkeznek, valamennyien hivatásos tüzoltók. A felmérés célja, hogy a korábbi Internetes felmérés adatait összevessem azzal, hogy „Milyen biztonsági szempontok alapján választ kötéltechnikai felszerelést?”, így mászógépet, ereszkedőgépet és karabinert. Az állítások kidolgozásánál a statisztikai módszerrel korábban feldolgozott válaszok eredményeit figyelembe vettem, így a biztonságos használatra vonatkozó gyártói javaslatot, a felhasználók körében a termékre vonatkozó elfogadottságot, a mentés során alkalmazott felszerelések együtt használatát, annak védőeszközökkel történő alkalmazhatóságát. A mászógép és az ereszkedőgép használatára vonatkozó állítások funkciót tekintve 50\%-ban azonosak voltak, viszont a karabinerre vonatkozó állítások értelemszerüen teljesen eltérőek voltak.

\section{A felmérés menete}

A 7 kötéltechnikai szakértő 2018. június 20-án egy gyakorlati felkészítés keretében rendezte a mászógépre, az ereszkedőgépre és a karabiner használatára összeállított 40-40 állítást egy 7 fokozatú $(-3,3)$ skála válaszrácsába. Az állítások kártyákon lettek megjelenítve. A kitöltést 
megelőzően a módszerről, a felmérés céljáról 20 percben felkészítést kaptak, azt követően az eszköztípusonkénti 40 kártyát 20 perc alatt rendezték, először a mászógépet, majd az ereszkedőgépet és a végén a karabinert.

\begin{tabular}{|c|c|c|}
\hline Sorszáma & Szakmai tapasztalat, év & Beosztás, szaktudás \\
\hline 1. & 17 & beosztott \\
\hline 2. & 22 & beosztott \\
\hline 3. & 5 & beosztott \\
\hline 4. & 15 & beosztott \\
\hline 5. & 21 & vezetö, szakértő \\
\hline 6. & 25 & vezetö, szakértő \\
\hline 7. & 19 & beosztott \\
\hline
\end{tabular}

1. táblázat A Q-módszertannal végzett felmérésbe bevont szakértők megoszlása szakmai tapasztalat és a HUNOR-ban betöltött beosztás szerint (saját szerkesztés)

A felmérés közel másfél órát vett igénybe. A kötéltechnikai felmérésbe bevont HUNOR állomány megoszlását a 1 . táblázat és az egyik szakértő válaszát a 2 . ábra tartalmazza, a rendezés helyzetét pedig a 3 . ábra mutatja.

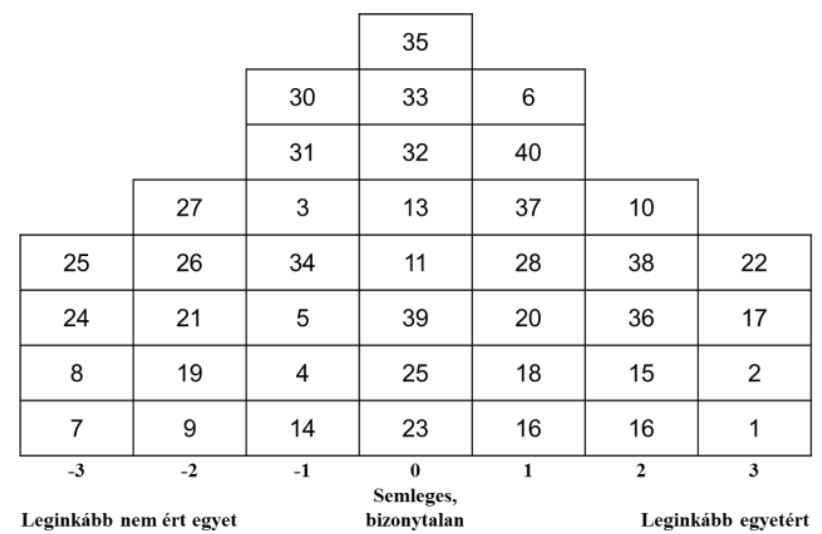

2. ábra A Q-módszertannal végzett felmérésegyik eredménye. A 7-es sorszámú válaszadó attitűdje az Ereszkedőgép biztonságos használatra történő kiválasztásánál (saját szerkesztés)

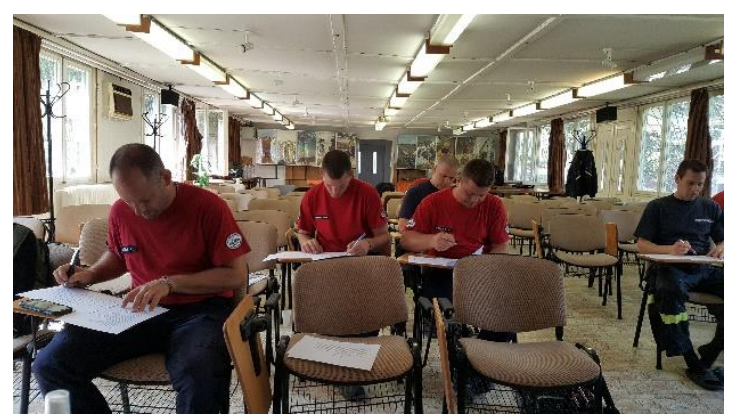

3. ábra A HUNOR Mentőszervezet kötéltechnikai mentési alegységének tagjai a felmérés - az állítások rendezése - közben (a szerző fotója)

\section{A Q-MÓDSZERTANNAL KAPOTT EREDMÉNYEK FELDOLGOZÁSA. A KAPOTT FAKTOROK ÉRTELMEZÉSE}

A hét rendezésre, mint változókra, elvégeztem a faktoranalízist, amely a mászógép és a karabiner esetében kettő, az ereszkedőgép esetében egy értelmezhető faktort adott eredményül. A legfontosabb eredmény a Rotated Component Matrix táblázatból jól látható, nevezetesen az, hogy a mászógép és a karabiner esetében az első főkomponens jól elkülönül a másiktól, így a kapott eredmények birtokában azokat külön alfejezetekben dolgozom fel és külön értelmezem. 


\section{Mászógép kiválasztására adott válaszok és azok értelmezése}

A faktorok értelmezésénél és a következtetések levonásánál azt kell figyelembe venni, hogy mely állítások azok, amelyek az egyes faktorokra leginkább, illetve leginkább nem jellemzőek. A skála két szélén lévő állítások fognak a legnagyobb magyarázó erővel bírni (a -3-hoz, illetve a +3-hoz közel esőek). Az így rendezett adatállományban az első öt legkisebb és első öt legnagyobb faktorpontokat értelmezzük a faktorok jelentésének a meghatározása céljából. Ezek a szélsőséges faktorpontokként kapott állítások támpontonként szolgálnak az első és a második faktor értelmezéséhez. Az első faktorhoz tartozó szakértök: 1, 2, 4, 5 és 6, a megoszlást a 2. táblázat mutatja be.

\begin{tabular}{|c|c|c|}
\hline \multirow{2}{*}{} & \multicolumn{2}{|c|}{ ComponentMatrix } \\
\cline { 2 - 3 } & 1 & 2 \\
\hline Expert_1 &, 839 &,- 156 \\
\hline Expert_2 &, 776 &,- 336 \\
\hline Expert_5 &, 726 &,- 337 \\
\hline Expert_4 &, 695 &, 302 \\
\hline Expert_6 &, 692 &,- 163 \\
\hline Expert_3 &, 575 &, 460 \\
\hline Expert_7 &, 416 &, 662 \\
\hline
\end{tabular}

2. táblázat A Q-módszertannal a Mászógépre végzett felmérés eredménye: két jól elkülönülő szakértői kör (kiemelve), 2 faktorra kapott eredménnyel (Expert=szakértő,Softver: SPSS, saját feldolgozás)

A Varimax rotációs eljárással végrehajtott faktoranalízis értékelhető eredményt adott: a KMO és Barlett's Test eredményei elfogadhatók ( $\mathrm{KMO}=0,828$, Barlett Sig.=,000). Az azonosított első fökomponens az összes variancia alig felét $(47,129 \%$ ), az első és a második együttesen már jóval több mint felét $(61,679 \%)$ magyarázza. Az eredményeket a 2. táblázat mutatja.

\begin{tabular}{|l|l|l|l|}
\hline \multicolumn{2}{|c|}{ Leginkább nem ért egyet (-3) } & \multicolumn{2}{c|}{ Leginkább egyetért (+3) } \\
\hline 1. & Az eszköz közkedveltsége. & 30. & Biztonságos használat. \\
\hline 9. & Az eszköz színe. & 38. & Kötél könnyü befüzése. \\
\hline 8. & Az eszköz bolti ára. & 20. & Az eszköz teherbírása. \\
\hline 25. & $\begin{array}{l}\text { A gyártó eszköz használatra } \\
\text { vonatkozó elórása. }\end{array}$ & 40. & Ritka meghibásodás. \\
\hline 27. & A gyártói ajánlás. & 2. & Az eszköz használatósága. \\
\hline
\end{tabular}

3. táblázat Az öt legkisebb (1., 9., 8., 25., 27.) és az öt legnagyobb (30., 38., 20., 40., 2.) faktorpontnak megfelelö állítások a Mászógép kiválasztásánál az első faktorba tartozó szakértők $(1,2,4,5,6)$ attitűdje alapján (saját szerkesztés)

Az első faktorban lévő válaszadók praktikus tapasztalatok alapján választanak mászógépet. Az eredményeket a 3. táblázat mutatja. A könnyü és biztonságos használat, a nagy teherbírás, a ritka meghibásodás előnybe részesítésével olyan szempontokat részesítenek előnyben, amellyel a letisztult müködésü konstrukciót, egyszerü mechanikus szerkezetet, jó anyagszerkezetü terméket kapnak a gyártól. A válaszadó szakértők a mászógégpre, mint biztonsági szerkezetre tekintenek, amelynek nagy szerepe van egy kötéltechnikai rendszer müködésében. A választásnál a kereskedelmi ár, az esztétikus kivitel és a divat nem befolyásoló tényező. A biztonságos használhatóságnál nem döntő a gyártói előírás és a használatra vonatkozó ajánlás, amelyet elsősorban a több évtizedes tapasztalat alapoz meg. A több éves felhasználói tapasztalat birtokában nem keresik a biztonságos használatra vonatkozó gyártói termékleírást, döntésükben inkább a saját tapasztalatra alapoznak. A válaszadó szakértők 3545 évesek és 15-25 éves kötéltechnikai felhasználói tapasztalattal rendelkeznek. 


\begin{tabular}{|l|l|l|l|}
\hline \multicolumn{2}{|c|}{ Leginkább nem ért egyet (-3) } & \multicolumn{2}{c|}{ Leginkább egyetért (+3) } \\
\hline 8. & Az eszköz bolti ára. & 6. & A kötéllel történö együtthasználhatóság. \\
\hline 9. & Az eszköz színe. & 1. & Az eszköz közkedveltsége. \\
\hline 38. & Kötél könnyü befüzése piszkos-sáros \\
\hline 32. & Könnyü kezelhetőség. & 22. & $\begin{array}{l}\text { Müködöképesség } \\
\text { körülmények között. }\end{array}$ \\
\hline 33. & $\begin{array}{l}\text { Védöeszközzel } \\
\text { kezelhetösége. }\end{array}$ & 12. & $\begin{array}{l}\text { Az eszköz } \\
\text { kezelhetősége. }\end{array}$ \\
\hline
\end{tabular}

4. táblázat Az öt legkisebb (8., 9., 38., 32., 33.) és az öt legnagyobb (6., 1., 22., 12., 17.) faktorpontnak megfelelő állítások a Mászógép kiválasztásánál a második faktorba tartozó szakértők $(3,7)$ attitüdje alapján (saját szerkesztés)

A második faktorban lévő válaszadók elsősorban a felhasználhatóság, a termék variálhatósága és extrém körülménye közötti alkalmazhatóságot keresik egy mászógép kiválasztásánál. Az eredményeket a 4. táblázat mutatja. A mászógépet egy közönséges kötéltechnikai eszközként kezelik, amelyet egy elérendö és leküzdendő cél felhasználása érdekében alkalmaznak. A választási attitüdjükben az eszköz közkedveltsége és együtthasználhatósága dominál, ők azok, akik a gyártói propagandának és reklámnak inkább jobban hisznek, mint a személyes tapasztalatnak. Olyan szerkezeti kialakítású termékeket keresnek, amelyek a biztonságos felhasználást segítik, átlátható müködéssel, továbbá más felszereléssel, így kötéllel könnyen együtt használható. A mászógép, mint szerkezet tekintetében a felhasználhatóság mérlegelésénél figyelembe veszik a környezeti tényezőket. A mászógép szerkezeti müködését befolyásoló piszkos-sáros körülmények előfordulását mérlegelik a termék kiválasztásánál, amely azt is jelentheti, hogy kevéssé foglalkoznak a termék és annak mozgó szerkezeti elemeinek a karbantartásával. A válaszadó szakértők 25-35 évesek és 5-15 éves kötéltechnikai felhasználói tapasztalattal rendelkeznek.

\section{Ereszkedőgép kiválasztására adott válaszok és azok értelmezése}

Az első faktorba valamennyi szakértő beletartozik, véleményalkotásukban egyetértés mutatkozik. A Varimax rotációs eljárással végrehajtott faktoranalízis értékelhető eredményt adott: a KMO és Barlett's Test eredményei elfogadhatók (KMO=0,813, Barlett Sig.=,000). Az azonosított fökomponens az összes variancia valamivel több, mint felét magyarázza $(58,172$ $\%)$. Az eredményeket az 5. táblázat mutatja.

\begin{tabular}{|c|c|}
\hline \multirow{2}{*}{ ComponentMatrix } \\
\cline { 2 - 2 } & Component \\
\hline Expert_1 &, 923 \\
\hline Expert_3 &, 841 \\
\hline Expert_5 &, 810 \\
\hline Expert_6 &, 798 \\
\hline Expert_2 &, 691 \\
\hline Expert_4 &, 644 \\
\hline Expert_7 &, 574 \\
\hline
\end{tabular}

5. táblázat A Q-módszertannal az Ereszkedőgépre végzett felmérés eredménye. Egyetlen faktorba tartozik mind a hét szakértő, attitüdükben nincs eltérés, teljesen egységes a megítélés (Expert=szakértő,Softver: SPSS, saját feldolgozás) 


\begin{tabular}{|l|l|l|l|}
\hline \multicolumn{2}{|c|}{ Leginkább nem ért egyet (-3) } & \multicolumn{2}{c|}{ Leginkább egyetért (+3) } \\
\hline 9. & Az eszköz színe. & 32. & Mászási/mentési biztonság. \\
\hline 7. & Az eszköz márkája (gyártó). & 13. & $\begin{array}{l}\text { Az eszköz által nyújtott } \\
\text { biztonságosság, védelmi képesség. }\end{array}$ \\
\hline 8. & Az eszköz bolti ára. & 33. & Biztonságos használat. \\
\hline 24. & Ereszkedőgép ár-értéke. & 12. & $\begin{array}{l}\text { Az eszköz használhatósága, } \\
\text { kezelhetősége. }\end{array}$ \\
\hline 40. & Kevés eszköz beszerzése szükséges. & 2. & Az eszköz használatósága. \\
\hline
\end{tabular}

6. táblázat Az öt legkisebb (9., 7., 8., 24., 40.) és az öt legnagyobb (32., 13., 33., 12., 2.) faktorpontnak megfelelő állítások a Ereszkedőgép kiválasztásánál a faktorba tartozó valamennyi szakértők (1-7) azonos attitűdje alapján (saját szerkesztés)

A szakértők egyöntetü véleményt adtak arra, hogy az ereszkedőgép kiválasztásában milyen szakmai tényezőket vesznek figyelembe. Az eredményeket a 6. táblázat mutatja. Mind a több éves és mind a néhány éves szakmai tapasztalattal rendelkezők azonos véleményen vannak. Az ereszkedőgép kiválasztásánál erősen dominál a biztonságos felhasználhatóság, alkalmazásával a biztonságos mászás vagy mentés támogatása. Használhatósági szempontoknál az eszköz egyszerü kezelhetősége, szerkezeti kialakítása, átlátható működése. Fontos a gyártó által garantált védelmi képesség, amely a biztonságos mászást vagy mentést garantálja. Az ereszkedőgép kiválasztásánál nem befolyásoló a termék márkája, elegáns kialakítása, designja és a kereskedelmi ára. A felhasználásával hajlandók a magasabb ár fekvésű ereszkedőgépet beszerezni, ha az biztonságosabb. A kötéltechnikai eszközök között drága piaci áru ereszkedőgép esetében hajlandók akár több eszközt tartalékként beszerezni, ha az a biztonságos felhasználást segíti.

\section{Karabiner kiválasztására adott válaszok és azok értelmezése}

A Varimax rotációs eljárással végrehajtott faktoranalízis értékelhető eredményt adott: a KMO és Barlett's Test eredményei elfogadhatók $(\mathrm{KMO}=0,824$, Barlett Sig.=,000). Az azonosított két fökomponens együttesen az összes variancia valamivel több, mint felét magyarázza $(58,387$ $\%)$. Az eredményeket a 7. táblázat mutatja.

\begin{tabular}{|c|c|c|}
\hline \multirow{2}{*}{} & \multicolumn{2}{|c|}{ ComponentMatrixa } \\
\cline { 2 - 3 } & 1 & 2 \\
\hline Expert_1 &, 889 &, 033 \\
\hline Expert_4 &, 888 &, 077 \\
\hline Expert_2 &, 859 &,- 231 \\
\hline Expert_3 &, 706 &, 532 \\
\hline Expert_7 &, 705 &,- 486 \\
\hline Expert_5 &, 638 &, 601 \\
\hline Expert_6 &, 607 &,- 521 \\
\hline
\end{tabular}

7. táblázat A Q-módszertannal a Karabínerre végzett felmérés eredménye: két jól elkülönülő szakértői kör (kiemelve), 2 faktorra kapott eredménnyel (Expert=szakértő,Softver: SPSS, saját feldolgozás)

\begin{tabular}{|l|l|l|l|}
\hline \multicolumn{2}{|c|}{ Leginkább nem ért egyet (-3) } & \multicolumn{2}{c|}{ Leginkább egyetért (+3) } \\
\hline 37. & Ár-anyag. & 21. & Kialakítás. \\
\hline 36. & Gyártó - karabiner piaci ára. & 4. & A karabiner kezelhetősége. \\
\hline 9. & Karabiner beszerzési ára. & 2. & A karabiner terhelhetősége. \\
\hline 8. & Karabiner gyártója, márkája. & 5. & A karabiner zár típusa. \\
\hline 34. & 10 db esetén a piaci ára. & 1. & A karabiner tömege. \\
\hline
\end{tabular}

8. táblázat Az öt legkisebb (37., 36., 9., 8., 34.) és az öt legnagyobb (21., 4., 2., 5., 1.) faktorpontnak megfelelő állítások a Karabiner kiválasztásánál a első faktorba tartozó szakértők $(1,2,3,4,7)$ attitüdje alapján (saját szerkesztés) 
Az első faktorban lévő válaszadók a könnyen kezelhető, nagy teherbírású, de kis tömegü karabinert keresik. Az eredményeket a 8. táblázat mutatja. A karabiner választásánál figyelembe veszik annak kialakítását és zártípusát, amely az egy kezes és egyéni védőeszközben (kesztyü) történő használatot könnyíti meg. A karabiner választásánál nem befolyásoló tényező a termék ára. Nem tesznek különbséget a gyártók, az egyes karabiner márkák között. Nagyobb tétel beszerzése esetén sem befolyásoló tényező a kereskedelmi kedvezmény. A karabiner használói a kis termék tömeg, mint kiemelt szempont mellett, a kiválasztásnál nem figyelik a termék anyagösszetételét (acél, alumínium ötvözet, stb.). A válaszadók azok a beosztott tüzoltók, akik mindennapi felhasználói a kötéltechnikai eszközöknek.

\begin{tabular}{|l|l|l|l|}
\hline \multicolumn{2}{|c|}{ Leginkább nem ért egyet (-3) } & \multicolumn{2}{c|}{ Leginkább egyetért (+3) } \\
\hline 1. & A karabiner tömege. & 7. & $\begin{array}{l}\text { A karabiner használat során szerzett } \\
\text { korábbi tapasztalat. }\end{array}$ \\
\hline 29. & Híres gyártó. & 18. & Biztonságos reteszelés tapasztalata. \\
\hline 5. & A karabiner zár típusa. & 33. & Könnyü, egykezes kezelhetőség. \\
\hline 30. & Szép kialakítás. & 4. & A karabiner kezelhetösége. \\
\hline 14. & Termék értékelések. & 12. & Mentési/mászási tapasztalat. \\
\hline
\end{tabular}

9. táblázat Az öt legkisebb (1., 29., 5., 30., 14.) és az öt legnagyobb (7., 18., 33., 4., 12.) faktorpontnak megfelelő állítások a Karabiner kiválasztásánál a második faktorba tartozó szakértők $(5,6)$ attitűdje alapján (saját szerkesztés)

A 2. faktorhoz tartozó válaszadók, azokat a karabinereket keresik, amelyek kezelhetősége könnyü és egyszerü, zárszerkezet reteszelése és egykezes kezeléssel is garantáltan üzembiztos. Az eredményeket a 9. táblázat mutatja. A karabiner kiválasztásánál a korábbi használati (mentési, mászási) tapasztalat fontos szerepet tölt be. A válaszadók elsősorban tapasztalati ismeretek alapján döntenek a karabiner kiválasztásában, döntésüket nem befolyásolja az elegáns, modern kivitel, a gyártói pozitív értékelések vagy a gyártói propaganda. A magas presztízsủ gyártótól származó termékeket nem értékelik tényleges értéküknél magasabbra, és nem döntő a választásban a karabiner tömege vagy annak zárt kialakítása sem. A 2. faktorban olyan vezetők vannak, akik nemcsak az irányításban vesznek részt, hanem tüzoltói munkájuk mellett szabadidejükben szakértői tevékenységet is ellátnak, legmagasabb kötéltechnikai szakértői végzettséggel rendelkeznek. Számukra a biztonság a fontos, amelyet a karabinerrel, mint kötéltechnikai eszközzel megnyugtatóan garantálni tudnak.

\section{KÖVETKEZTETÉSEK}

A biztonsági kockázatok csökkentését célzó felmérés, a nagyon speciális, szük felhasználói körrel rendelkező kötéltechnikai mentéseket végző személyek eszközhasználatát mérte fel a Q módszertannal. A felmérés kiegészítése egy korábbi Internetes felmérésnek, ahol az idős és fiatal felhasználók biztonságra vonatkozó érdeklődését vizsgáltam. Az ott feldolgozott tapasztalatok alapján kerültek kidolgozásra a mászógép, az ereszkedőgép és a karabiner használatára vonatkozó állítások. A Q-módszertan lehetővé tette, hogy 7 kötéltechnikai szakértő biztonságos használatot érintő termékválasztási attitüdjét vizsgáljuk. A tapasztalatok alapján a gyártók számára javaslatokat tudtunk megfogalmazni annak alapján, hogy a felhasználók hogyan viszonyulnak a biztonság kérdéséhez[12][13].

Jól látható, hogy a tapasztalatlan, kevés rutinnal rendelkezők jobban figyelnek a gyártói utasításokra, gyártói ajánlásokra, biztonsági tesztekre. Számukra egy adott termék csupán sokadik a sok kötéltechnikai eszköz között, ezért hangsúlyozni kell a fiatal felhasználók számára a mászógép és ereszkedőgép fö biztonsági szerepét. Karabiner esetében a gyors alkalmazásba helyezés és a könnyen kezelhetőség a fő befolyásoló tényező[14][15]. A vizsgált 3 termékcsoport közül nem érdekli a fiatal felhasználókat, hogy az adott kötéltechnikai eszköz „,hogyan és miként müködik”, milyen új technikai megoldásokat, új fejlesztésü anyagösszetételt 
tartalmaz. Megállapítható, hogy ez a csoport a „felületes felhasználók” csoportja, akik számára például az eszköz karbantartása nem elsődleges, hiszen a felszerelés müködése iránt nem érdeklődnek, ezért az 5-15 éves fiatal felhasználók termékhasználata magasabb biztonsági kockázatot rejt.

Ellentétes ezzel az idősebb, nagyobb tapasztalattal és irányítói gyakorlattal rendelkezők viszonyulása, akik számára a biztonságos termékhasználat, a biztonság kérdése nagyon fontos. A kötéltechnikai felszerelések kiválasztásánál és használatánál 15-25 éves felhasználók körében, a praktikum, a hagyományos termékkialakítás, az átlátható és biztos mechanikájú szerkezetek a közkedveltek. A 3 eszközcsoport esetében a gyakorlati tapasztalat erősebb a gyártói ajánlásnál. Új termék bevezetése, új módszerek elfogadtatása sokkal nehezebb. A „régi beidegzödések” és a „saját börömön már megtapasztaltam” felfogás mellett viszonylag nehéz a gyártói termékfejlesztéseket sikerre vinni és az új biztonsági megoldásokat bevezetni [16][17]. A rutinnal rendelkező felhasználókat a biztonságot erősítő attitüddel lehet rávezetni a modern termékek használatára és nem a felszínesen „designos” kialakítással. A több évtizedes tapasztalattal rendelkezők ismerni akarják az eszköz müködését, mechanikai összetételét, így ha a gyártó egy bonyolultabb szerkezetủ új eszközt kíván bevezetni, akkor annak bemutatását a biztonságos használat oldaláról kell megközelíteni, hangsúlyt fektetve a mozgó mechanikus elemek mozgásának szemléletes modellezésére is (a „hogyan müködik, mitöl biztonságos?” kérdésre adjunk elsősorban választ). Az idősebb felhasználók nem bíznak a modern termékek biztonságosságában, viszont megismerésük és sikeres alkalmazásuk esetén kulcsfontosságú figyelmet kaphat részükröl az eszköz [18].

Összességében megállapítható, hogy mind a fiatal és mind az idős kötéltechnikai termékfelhasználók esetében vannak biztonsági kockázatok, amelyek azonban jellegzetesen eltérőek. Amíg a fiatalok lelkes felhasználók, nyitottak az újra, addig az idősebb, de már szakértői szinten dolgozók tudatos, de ugyanakkor bizalmatlan felhasználók. Mindét csoport felé a gyártóknak erősíteni kell a gyártói ajánlásokat. Gyakorlatok esetén más-más módszerrel kell a felhasználókat felkészíteni [19].

\section{A KAPOTT EREDMÉNYEK HASZNOSÍTHATÓSÁGA}

A biztonsági kockázatok csökkentését és a biztonságos felszerelés-használatot célzó statisztikai módszerekkel végzett felmérés megalapozott operatív javaslatok megfogalmazását teszi lehetővé, amelyek bevezetése így, mind a gyártók, mind a mentést végző szervezetek vezetői számára indokolható,

- eljárásrendek bevezetése, illetve biztonságosság terén annak jobbítása,

- gyártói útmutatók fejlesztése, annak felhasználóbaráttá tétele,

- új mentési, önmentési felszerelések alkalmazása,

- extrém környezetben történő mentések hatásmechanizmusának megértése terén.

\section{Új személyi kötéltechnikai védőeszköz használatának bevezetése}

Az EXO Hook a Petzl egyéni mentőeszköze tűzoltók számára, melynek segítségével egy személy szükség esetén kimenekülhet egy épületből vagy szerkezetről. A kampóval ellátott változat olyan esetekre ajánlott, melyekben a felhasználó valószínüleg nem talál konkrét kikötési pontot.

A felszerelés egy kombinált személyi menekülési rendszer, melynek nagyméretü kampója (hook) olyan helyekhez igazodik, ahol kikötési pont megtalálásának lehetősége bizonytalan, például romos vagy lángoló épületeknél. A felszerelés rendelkezik egy önfékező rendszer pánikellenes funkcióval a vízszintes gyors haladáshoz ablakon vagy épületperemen áthaladva, és az ereszkedés szabályozására és fékezésére. Ha a felhasználó túlságosan húzza a fogantyút, 
az anti-pánik funkció fékezi és automatikusan leállítja a süllyedést. A felszerelés egy zsákban, egy olyan kötelet is tartalmaz, amely ellenáll a kopásnak és a magas hőmérsékletnek.

\section{Mentési környezeti kockázatok ismerete, a veszély zóna fogalom bevezetése}

A doktori kutatás további lépése az, hogy matematikai módszerekkel a nagy kockázatot jelentő veszély zóna (Danger Zone) meghatározását megkísérelje, így megértve az extrém környezetben (havas, saras, csúszós terepen) történő mentések hatásmechanizmusát. A mérhető környezeti hatások (nedves terep, hőmérséklet, védőeszköz típusa, jégvastagság) ismeretében, azok kockázat-elemzésével, remélhetően konkrét biztonsági megelőző óvintézkedések lesznek megfogalmazhatók a felhasználók számára.

\section{ÖSSZEGZÉS}

A Különleges mentési felszerelések biztonságos használatának elemzése statisztikai módszerekkel történő megközelítésben újnak mondható következtetéseket adott a felhasználó, a gyártó, a mentést irányító szervezet és a szervezeti eljárások terén. Rávilágított arra, hogy eljárásrendek bevezetésével, a gyártói utasítások megújítása, a tudatos felkészítés az eszköz használatára erősíti a kötéltechnikai eszközök biztonságos felhasználását, illetve alkalmazását. A felhasználók szubjektív attitüdjének több statisztikai módszerrel történő elemzése biztosította azt, hogy megalapozott objektív következtetéseket lehessen levonni, tanulni abból, hogy a felszerelések használóit mi motiválja a felszerelések kiválasztásánál és használatánál. Az eredmények alapján a mentést végző tüzoltók és a mentési felszereléseket forgalmazó cégek számára fejlesztési javaslatokat tudtam megfogalmazni.

A kapott eredmények birtokában és a kötéltechnikai felhasználók véleményét megismerve fogalmazódott meg az igény, hogy három kiválasztott felszerelés-csoporthoz kapcsolódó összegzett megállapításokról kérdezzem meg a kötéltechnikai felszereléseket forgalmazó és gyártó nemzetközi cégeket, amely a kutatásom következő lépését képezi.

\section{FELHASZNÁLT IRODALOM}

[1] HORVÁTH Á.: A szubjektivitás számszerüsítésének lehetősége a Q-módszertan segítségével, 1 p p. www.eco.u-szeged.hu/download.php?docID=40104 (Letöltés: 2017.10.13.)

[2] BROWN, S. R. [1996]: Q Methodology and Qualitative Research. In: Qualitative Health Research, 6. 4., 561-567 pp

[3] BAKER, R., THOMPSON, C., MANNINON R. [2006]: Q Methodology in Health Economics. Journal of Health Services Research and Policy. Vol. 11. No. 1. 38-45. pp

[4] GULÁCS L.: Gyakorló orvosok egészségnyereség társadalmi elosztásával kapcsolatos attitüdje - a Q-vizsgálat, Statisztikai Szemle, 89. évfolyam 9. szám, 982 pp.

[5] IZSÓ L., HORVÁTH Á. G.: Szubjektív vélekedés-rendszerek objektív vizsgálatának lehetőségei a Q-módszertan segítségével, Alkalmazott Pszichológia VIII. évfolyam 4. szám (2006) 109-138.

[6] IZSÓ L.: A Qhódszertan és alkalmazásai, egyetemi előadás - 2017, BME APPI Ergonómia és Pszichológia Tanszék,

[7] KETSKEMÉTY L., IZSÓ L., KÖNYVES T.E.: Bevezetés az IBM SPSS Statistics programrendszerbe; Artéria Stúdió Kft. 2011.,157., 438. o. 
[8] IZSÓ L.: Statisztikai elemzések, SPSS gyakorlatok; egyetemi előadás (2017), BME APPI Ergonómia és Pszichológia Tanszék

[9] SZUNYOGH G.: Biztonsági kockázatok a természeti környezetben, egyetemi elöadás (2017) Óbudai Egyetem Bánki Donát Gépész és Biztonságtechnikai Mérnöki Kar

[10] VAN EXEL NJA, G DE GRAFF: Q methodology: A sneak preview. 2005 [availablefromwww.jobvanexel.nl] (Letöltés: 2017.12.11.)

[11] KELLY S.E, MOHER D., CLIFFORD T.J.: Expediting evidence synthesis for health care decision-making: exploring attitudes and perceptions towards rapid reviews using $\mathrm{Q}$ methodology. (2016) PeerJ4:e2522https://doi.org/10.7717/peerj.2522 (Letöltés: 2017.12.11.)

[12] ANTAL Ö., MUHORAY Á.: A földrengés katasztrófák által okozott szerkezeti omlásokkal kapcsolatos kutatás-mentési feladatok alkalmazott módszerei; Hadmérnök, IX. 2. (2014) 13. o.

[13] MUHORAY Á.: A polgári védelem helye és szerepe, feladata hazánkban a XXI. század elsö évtizedében; Polgári Védelmi Szemle, Budapest, 2010., 29-32. o.

[14] BÉRCZI L.: Az extrém körülmények közötti tüzoltói beavatkozások biztonságát növelö eszközrendszer fejlesztések az integrált katasztrófavédelem rendszerében; Doktori (PhD) értekezés (2014) 1-181. o., DOI azonosító: 10.17625/NKE.2014.010

[15] JACKOVICS P.: Kötéltechnikai mentési alapfelszerelések rendeltetésének értékelése; Védelem Tudomány: Katasztrófavédelmi Online Tudományos folyóirat; 2016. (2.) pp. 556-586. o.

[16] JACKOVICS P.: A barlangi balesetek és mentések adatainak elemzése; Hadmérnök, XI. 3. (2016) 57-74. o.

[17] JACKOVICS P.: Standard of operation for cave rescue in Hungary; International FireFighter, 2016 (9)pp. 84-86

[18] JACKOVICS P.: New Professional Guidelines in Hungary; FireRescueMagazine2016. (11) pp. 50-56

[19] BLESZITY J., FÖLDI L., HAIG Zs., NEMESLAKI A., RESTÁS Á.: Müszaki kutatások és hatékony kormányzás, Hadmérnök, XI. 3. (2016) 223. o. 


\section{FÜGGELÉKEK}

1. függelék A Q-módszertannal rangsorolt állítások eszközcsoportonként, a vizsgálathoz kiadott szöveggel (saját szerkesztés)

Feladat: Kérem, válaszoljon az alábbi kérdésre, az Ön előtt álló kártyán szereplő állítások kiválogatásával!

Kérdés: Ön milyen biztonsági szempontok alapján választ kötéltechnikai felszerelést?

Kérem, a válaszrácsban rangsorolja az állításokat! A 40 kártyából először válasza azt a 4 kártyát, amelynek az állításával egyáltalán nem ért egyet és a négy sorszámot írja be az értékrács szélső -3 értékéhez. Ezt követően válassza ki azt a 4 kártyát, amelynek az állításával teljes mértékben egyetért és a négy sorszámot írja be az értékrács szélső +3 értékéhez. Folytassa a kártyák kiválasztását a -2 és a +2 értékhez tartozó állításokkal egészen a 0 értékig, amíg azok a kártyák maradnak, amelyek Ön szerint nem lényegesek a felszerelések kiválasztásánál.

Egy állítást egyszer használjon fel! Minden rácspontba írjon be egy kártya sorszámot!

\section{Mászógépre vonatkozó állítások kártyái:}

1. Az eszköz közkedveltsége.

2. Az eszköz használatósága.

3. Az eszköz szerepe a biztonságos munkavégzésben.

4. Az eszköz használata során növeli a teljesítményemet.

5. A kötéltechnikai müveletek hatékonysága.

6. A kötéllel történő együtthasználhatóság.

7. Az eszköz márkája (gyártó).

8. Az eszköz bolti ára.

9. Az eszköz színe.

10. Az eszköz kényelmes használata.

11. Az eszköz rendeltetése, funkciója.

12. Az eszköz használhatósága, kezelhetősége.

13. Az eszköz által nyújtott biztonságosság, védelmi képesség.

14. Az eszköz tömege.

15. Az eszközöz használata során szerzett tapasztalatok.

16. Az eszközhasználathoz adott gyártói javaslat.

17. Az eszköz meglévő eszközeivel való együtt használata, kompatibilitás.

18. Az eszközre adott gyártói garancia ideje vagy megléte.

19. Az eszköz karbantarthatósága.

20. Az eszköz teherbírása.

21. Az eszköz használatba helyezés gyorsasága!

22. Müködőképesség piszkos-sáros körülmények között!

23. Használat során az önbiztosítás szükségessége!

24. Mászógép(ek) egykezes vagy kétkezes használatósága.

25. A gyártó eszköz használatra vonatkozó előírása.

26. A gyártó biztonságosra vonatkozó előírása.

27. A gyártói ajánlás.

28. Gyártói kezelési útmutatás.

29. Mászási/mentési biztonság.

30. Biztonságos használat.

31. Az eszköz önbiztosításban betöltött szerepe.

32. Könnyü kezelhetőség. 
33. Védőeszközzel történő kezelhetősége.

34. Eszköz mindennapi használata.

35. Könnyü használat.

36. Könnyü karbantarthatóság.

37. Érthető használati utasítás.

38. Kötél könnyü befüzése.

39. Eszköz technikai fejlettsége.

40. Ritka meghibásodás.

\section{Ereszkedőgépre vonatkozó állítások kártyái:}

1. Az eszköz közkedveltsége.

2. Az eszköz használatósága.

3. Az eszköz szerepe a biztonságos munkavégzésben.

4. Az eszköz használata során növeli a teljesítményemet.

5. A kötéltechnikai müveletek hatékonysága.

6. A kötéllel történő együtthasználhatóság.

7. Az eszköz márkája (gyártó).

8. Az eszköz bolti ára.

9. Az eszköz színe.

10. Az eszköz kényelmes használata.

11. Az eszköz rendeltetése, funkciója.

12. Az eszköz használhatósága, kezelhetősége.

13. Az eszköz által nyújtott biztonságosság, védelmi képesség.

14. Az eszköz tömege.

15. Az eszközöz használata során szerzett tapasztalatok.

16. Az eszközhasználathoz adott gyártói javaslat.

17. Az eszköz meglévő eszközeivel való együtt használata, kompatibilitás.

18. Az eszközre adott gyártói garancia ideje vagy megléte.

19. Az eszköz karbantarthatósága.

20. Az eszköz teherbírása.

21. Az eszköz használatba helyezés gyorsasága!

22. Müködőképesség piszkos-sáros körülmények között!

23. Használat során az önbiztosítás nagyobb szükségessége!

24. Ereszkedőgép ár-értéke.

25. Ereszkedőgép újszerü kialakítása.

26. Korszerü fejlesztése.

27. Korszerü müszaki megoldások.

28. Biztonságos müszaki megoldás.

29. A gyártó eszköz használatra vonatkozó elöírása.

30. A gyártó biztonságosra vonatkozó elöírása.

31. Gyártói kezelési útmutatás.

32. Mászási/mentési biztonság.

33. Biztonságos használat.

34. Az eszköz önbiztosításban betöltött szerepe.

35. Eszköz mindennapi használata.

36. Könnyű használat.

37. Könnyü karbantarthatóság.

38. Kompatibilitás más eszközzel.

39. Helyettesíthetőség.

40. Kevés eszköz beszerzése szükséges. 


\section{Karabinerre vonatkozó állítások kártyái:}

1. A karabiner tömege.

2. A karabiner terhelhetősége.

3. A karabiner anyaga.

4. A karabiner kezelhetősége

5. A karabiner zár típusa.

6. A karabiner más felszereléssel történő együtt használata.

7. A karabiner használat során szerzett korábbi tapasztalat.

8. Karabiner gyártója, márkája.

9. Karabiner beszerzési ára.

10. Karabiner kompatibilitása.

11. Karabiner kötéllel történő használata.

12. Mentési/mászási tapasztalat.

13. Társak, munkatársak tapasztalata.

14. Termék értékelések.

15. Kezelhetőségre vonatkozó tapasztalat.

16. Zárszerkezet kezelhetöségével kapcsolatos tapasztalat.

17. Védőkesztyüben történő használat.

18. Biztonságos reteszelés tapasztalata.

19. Terhelhetőségi tapasztalat.

20. Más gyártói eszközzel történő együtt használat.

21. Kialakítás.

22. Kialakításból adódó más eszközzel történő együtthasználat.

23. Könnyü tömeg.

24. Kemény anyagú karabiner.

25. Karabiner kopása.

26. Karabiner megnyúlás.

27. Terhelhetöség,

28. Többszöri használat.

29. Híres gyártó.

30. Szép kialakítás.

31. Reteszelés modern kialakítása.

32. Gyors reteszelés.

33. Könnyü, egykezes kezelhetőség.

34. $10 \mathrm{db}$ esetén a piaci ára.

35. Ár - érték.

36. Gyártó - karabiner piaci ára.

37. Ár-anyag.

38. Ár-tömeg.

39. Méret-tömeg.

40. Terhelhetőség-tömeg. 